\title{
EFFECTS OF ENDOGENOUS AND EXOGENOUS GLUCOCORTICOIDS ON LIVER DIFFERENTIATION
}

\author{
Celia Machín, ${ }^{1 *}$ Carmen Rúa, ${ }^{1}$ Begoña Diaz ${ }^{1}$ and Rosa María Arahuetes ${ }^{2}$ \\ ${ }^{1}$ Dpto. Biología Celular. and \\ ${ }^{2}$ Dpto. Biología Animal II. Facultad C. C. Biológicas Universidad Complutense, \\ Ciudadad Universitaria, 28040 Madrid, Spain
}

(Received: May 20, 1999; accepted: November 27, 1999)

\begin{abstract}
The effects of maternal bilateral adrenalectomy on day 1 of gestation and betamethasone treatment on fetal liver development were compared, in terms of biochemical and morphological parameters. For fetuses 20 days old (E20), absence of maternal glucocorticoids during gestation caused an increase in the number of nuclei in whole livers, and a significantly decrease of both body weight and protein content per nucleus, in comparison with the control group (C). Betamethasone injection on days 15, 16 and 17 of gestation into adrenalectomized pregnant rats $(\mathrm{ADX}+\mathrm{BET})$ did not completely prevent these effects.

The electron microscopic analysis of the ADX fetal liver (E20) showed some hepatocyte lesions such as loss of cytoplasmic organelles, increase in hematopoietic cell number as well as a lower cellular maturation in comparison with the control group. The fetal liver from ADX + BET mothers 20 days after gestation displayed a noticeable involution of the hematopoietic component in spite of its relatively immature stage. However, there was no significant change in the degree of fetal hepatocyte lesions.

Therefore, supply of maternal glucocorticoids from the beginning of gestation is essential for maintenance of the integral structure of the rat fetal hepatic parenchyma, for the correct maturation of the blood strains and for the beginning of involution of the hematopoietic tissue at the end of gestation.
\end{abstract}

Keywords: Fetal liver - glucocorticoids - adrenalectomy

\section{INTRODUCTION}

Glucocorticoids (GCs), like other steroid hormones, are thought to act by controlling the rate of protein syntesis [17]. GCs react with receptor proteins in the target cytoplasm and form a steroid-receptor complex which regulates specific gene expression in the nucleus of the target cell and results in the biological responses as described $[15,16]$. As suggested $[3,27]$, the number of the binding sites of glucocorticoid receptor to nuclei may be involved in the efficacy of the glucocorticoid in addition to the affinity of the glucocorticoid to the receptor of the cytoplasm.

On the other hand, GCs play an important role in the cellular development process $[2,14]$. These hormones might exert a control on the expression of many hepatic and

\footnotetext{
*Corresponding author; Fax: +34/91/3944981
} 
cerebral genes both in vivo and in vitro $[21,26]$ necessary for normal maturation. Studies carried out in our laboratory $[1,30,34,35]$, showed the relevance of CGs in prenatal rat brain in control mechanisms of cellular division and maturation; we also tested the influence of GCs on prenatal biochemical maturation [4, 20]. Fetal serum levels of corticosterone are very low in both sexes during the two first weeks of gestation in the rat. The hormone is secreted by the mother. At embryonic day E17, E18, the levels increase when the fetal adrenal gland begins to secrete, and remain high during E19, subsequently it slightly decreases. Immediately before and during the labor, the levels increase again $[7,9,19,25,36]$.

GCs also play an important role in both the structural and functional maturation of fetal liver; they are involved in the beginning of glycogen storage from day 18th of pregnancy [18] and in the cellular differentiation of fetal hepatocytes [33]. Besides, they influence regulation of fetal hematopoietic activity, this function being carried out through the hepatocytes which are a part of the inductive hematopoietic enviroment of the organ [28]. Studies by Mayeux et al. [24], demonstrated that GCs inhibit erythropoietin synthesis by fetal hepatocytes in culture. The aim of the present work was to examine the nature and extent of the control exerted by GCs on prenatal morphogenesis in the fetal liver.

\section{MATERIAL AND METHODS}

Twenty-two Albino rats (Rattus norvegicus) Sprague-Dawley strain, weighing between 180 and $200 \mathrm{~g}$, were used for this study. The animals were conditioned for 3 weeks to a controlled temperature of $28{ }^{\circ} \mathrm{C}$, received standard food ad libitum and a light cycle of $12: 12 \mathrm{~h}$, inverted with regard to day-night cycle (dark phase between 8.00 a.m. and 8.00 p.m.). Females were caged overnight with males and conception was assumed the next morning on basis of the presence of spermatozoa in the vagina; this was designated as day 0 of gestation. The animals were assigned to the following treatment groups: 1. sham-operated controls (C); 2. bilaterally adrenalectomized on day 1 of gestation (ADX); 3. adrenalectomized on day 1 and betamethasone-injected on days 15, 16 and 17 (ADX + BET). The number of animals under study in each group was of 6-7 litters (8-14 fetuses/litter). No differences between sexes of the fetuses were made.

Twenty-four hours after the presence of sperm was determined, rats for ADX and $\mathrm{ADX}+\mathrm{BET}$ groups were anaesthetized with ether and adrenalectomized bilaterally. All adrenalectomized rats received $0.9 \%$ saline in drinking water during gestation up to day 20. At the first hour on gestational days 15, 16, and 17, dams for ADX + BET group was administered $0.085 \mathrm{mg} / \mathrm{kg}$ of body weight of betamethasone (Betnovate liquid : betamethasone as 17 -valerate, $1 \mathrm{mg} / \mathrm{ml}$, Glaxo), while $\mathrm{C}$ and ADX groups received equivalent volumes of isotonic saline vehicle $(0.085 \mathrm{ml} / \mathrm{kg})$.

On days 17 and 20 of gestation (E17; E20), pregnant rats were decapitated and fetuses then were taken from the uterus after histerotomy. Immediately thereafter, four fetuses for each treatment group were decapitated. Livers were removed and 
weighted. The tissue was then homogenized in a saline $(0.9 \%)$-ethanol (95\%) solution. Total liver protein content was assayed by the method of Lowry et al. [22]. For DNA measurement, the method of Schneider [32], was used. For determination or total lipids, the tissue was homogeneized in chloroform-methanol $(2: 1)$ solution and assayed by the method of Folch et al. [12]. Protein and DNA contents were used to determine the number or nuclei per liver and cell size by means of the equations proposed by Enesco and Leblond [11].

For electron microscopic study four fetuses from groups E17 and E20 were quickly removed and their livers were immediately fixed by immersion in a mixture of $4 \%$ paraformaldehyde and $2.5 \%$ glutaraldehyde in $0.1 \mathrm{M}$ phosphate buffered saline solution ( $\mathrm{pH} \mathrm{7.4)}$ ) at $4{ }^{\circ} \mathrm{C}$ for $3 \mathrm{~h}$. Small liver pieces were postfixed with $2 \%$ osmium tetroxide in phosphate buffer, dehydrated in acetone, infiltrated with propylene oxide and embedded in Epon. Blocks were trimmed and semithin sections $1 \mu \mathrm{m}$ thick were cut with a Reichert OM-U3 ultratome and stained with toluidine blue-borax. Selected blocks were trimmed again and cut $40 \mathrm{~nm}$ thick with a diamond Knife; sections were picked up on copper plates and stained with $2 \%$ uranyl acetate. Analysis and photographs were made with a Zeiss 902 electron microscope.

\section{Statistical analysis}

Student's test for independent groups was used for statistical free comparison of the different parameters studied. A value of $p<0.05$ was considered to be significant.

\section{RESULTS}

Twenty days after gestation, ADX fetal body weight was significantly lower than in the control group and fetal liver weight also was affected by maternal treatment as shown in Table 1. Recovery of weight in fetal body and liver was observed in $\mathrm{ADX}+\mathrm{BET}$ group.

Maternal adrenalectomy on day 1 of gestation caused a significant decrease in fetal liver protein content in relation to control as shown in Table 2. DNA levels in E20 liver from ADX mothers increased by $9 \%$ in relation with controls although this

Table 1

Effects of maternal ADX and BET treatment of fetal body an liver weights

\begin{tabular}{lccc}
\hline & Body weight $(\mathrm{g})$ & Liver weight $(\mathrm{mg})$ & Liver W/Body W (\%) \\
\hline Control $(\mathrm{n}=7)$ & $3.43 \pm 0.49$ & $249.8 \pm 11.0$ & $7.08 \pm 0.78$ \\
ADX $(\mathrm{n}=7)$ & $2.89 \pm 0.28^{*}$ & $212.2 \pm 14.1$ & $7.15 \pm 0.43$ \\
ADX + BET $(\mathrm{n}=6)$ & $3.10 \pm 0.42$ & $220.4 \pm 17.2$ & $6.91 \pm 0.30$ \\
\hline
\end{tabular}

Values are means $\mathrm{SE} * \mathrm{P}<0.05$, Student's $t$-test, significantly different from controls. 
Table 2

Effects of maternal ADX and BET treatment of fetal liver DNA, protein and lipid contents

\begin{tabular}{llll}
\hline & $\begin{array}{c}\text { DNA } \\
(\mathrm{mg} / \text { liver })\end{array}$ & $\begin{array}{c}\text { Protein } \\
(\mathrm{mg} / \text { liver })\end{array}$ & $\begin{array}{c}\text { Lipid } \\
(\mathrm{mg} / \text { liver })\end{array}$ \\
\hline Control $(\mathrm{n}=7)$ & $0.56 \pm 0.06$ & $36.5 \pm 3.89$ & $4.04 \pm 0.90$ \\
ADX $(\mathrm{n}=6)$ & $0.61 \pm 0.08$ & $31.7 \pm 4.83^{*}$ & $3.71 \pm 0.70$ \\
ADX + BET $(\mathrm{n}=6)$ & $0.70 \pm 0.05$ & $36.0 \pm 4.61^{* *}$ & $3.45 \pm 0.50$ \\
\hline
\end{tabular}

Values are means $\mathrm{SE} * \mathrm{P}<0.05$, Student's $t$-test, significantly different from controls.

**Significantly different from ADX.

difference was not statistically significant. Betamethasone treatment of ADX pregnant rats (ADX + BET) showed that fetal liver DNA content did not significantly differ from that of the ADX group, but it was higher than the DNA control (Table 2). No statistically significant differences in fetal liver lipid contents were observed among these three experimental groups (Table 2) although all the experimental groups had values slightly lower than the values we found in the control group. The cell number (nuclei/liver) of E20 liver from ADX group was significantly higher than in the control group, as shown in Table 3. The protein content per nucleus is significantly lower in ADX than in the control group (Table 3). However, the average cell number in ADX + BET group (Table 3) did not significantly differ from both control values and ADX group. Fetal liver protein content, affected by maternal adrenalectomy showed an increase in ADX + BET group. The protein/nucleus ratio was lower in fetuses of $\mathrm{ADX}+\mathrm{BET}$ group than in controls and did not differ from ADX group.

Table 3

Effects of maternal ADX and BET treatment on cell number (nuclei/liver) and cell size (protein/nucleus)

\begin{tabular}{lcc}
\hline & Nuclei $\times 10^{6} /$ liver & Protein/Nucleus \\
\hline Control $(n=7)$ & $90.3 \pm 9.0$ & $410.2 \pm 28.1$ \\
ADX $(n=6)$ & $120.0 \pm 10^{*}$ & $306.0 \pm 13.8^{*}$ \\
ADX + BET $(n=6)$ & $112.1 \pm 7.5$ & $307.4 \pm 40.0^{*}$ \\
\hline
\end{tabular}

Values are means $\mathrm{SE} * \mathrm{P}<0.05$, Student's $t$-test, significantly different from controls.

**Significantly different from ADX.

\section{CONTROL groups}

After 17 days of gestation, before the onset of fetal glucocorticoid production, the hepatic cords contained many erythroblastic islands, and phagocytes were distinguishable. The immature hepatocytes were stellate or irregular in shape, and pos- 

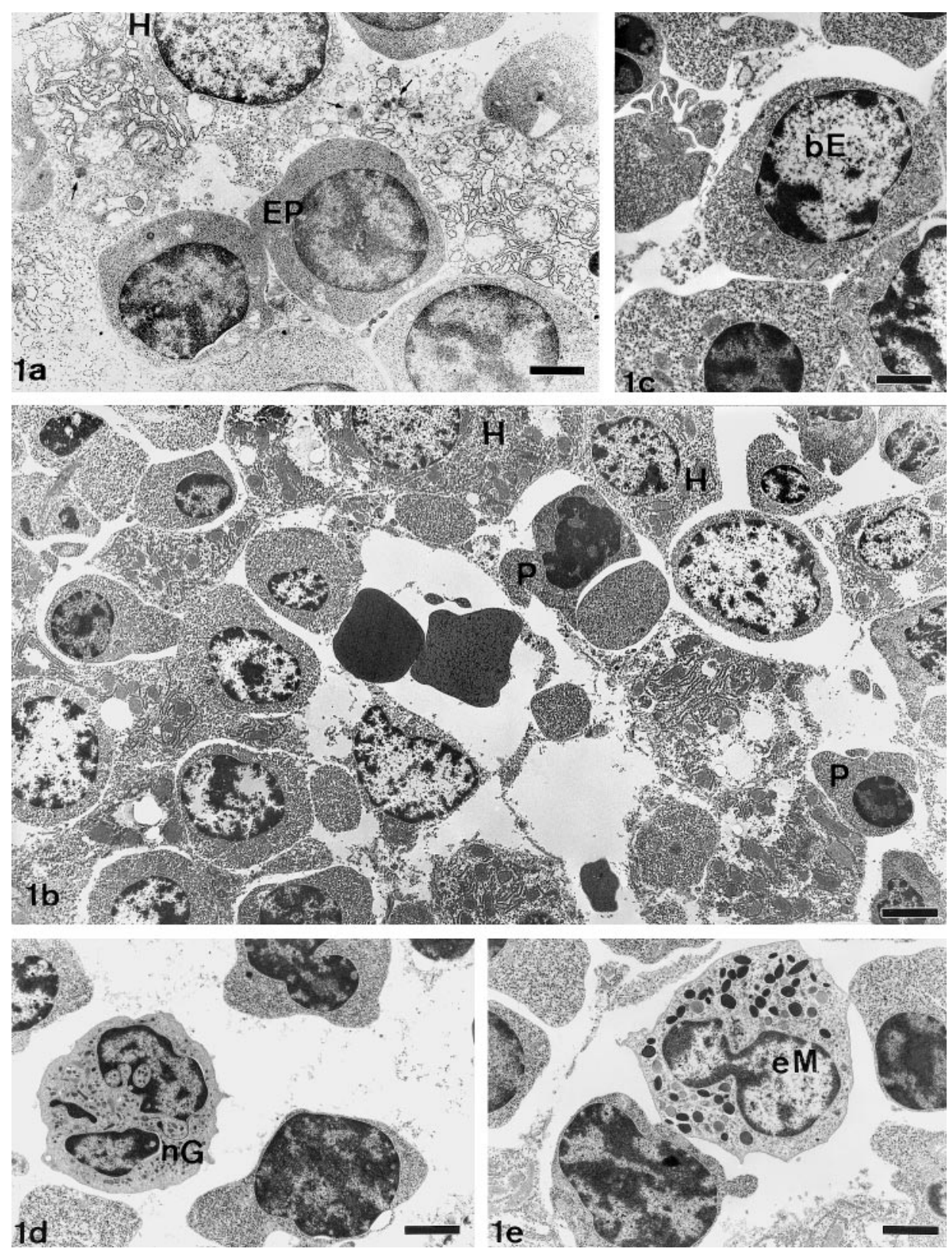

Fig. 1a. Immature hepatocytes in the primitive hepatic cords after 17 days of gestation. The hepatocyte $(\mathrm{H})$ contains many mitochondria, relatively abundant endoplasmic reticulum and a few small lysosomal granules (arrows) in the cytoplasm. EP: immature erythropoietic cells. Scale bar: $3 \mu \mathrm{m}$. Fig. 1 b. Electron micrograph of E-20 fetal liver from Control group (E-20 C). Cords of immature hepatocytes $(\mathrm{H})$ and hematopoietic cells (P) can be observed. Scale bar: $5 \mu \mathrm{m}$. Fig. 1c. E-20 C. Basophilic erythroblast (bE). Escale bar: $1.8 \mu \mathrm{m}$. Fig. $1 d-1 e$. E-20 C. Mature neutrophilic granulocyte (nG) and eosinophilic metamyelocyte (eM). Scale bar: $2.5 \mu \mathrm{m}$ 

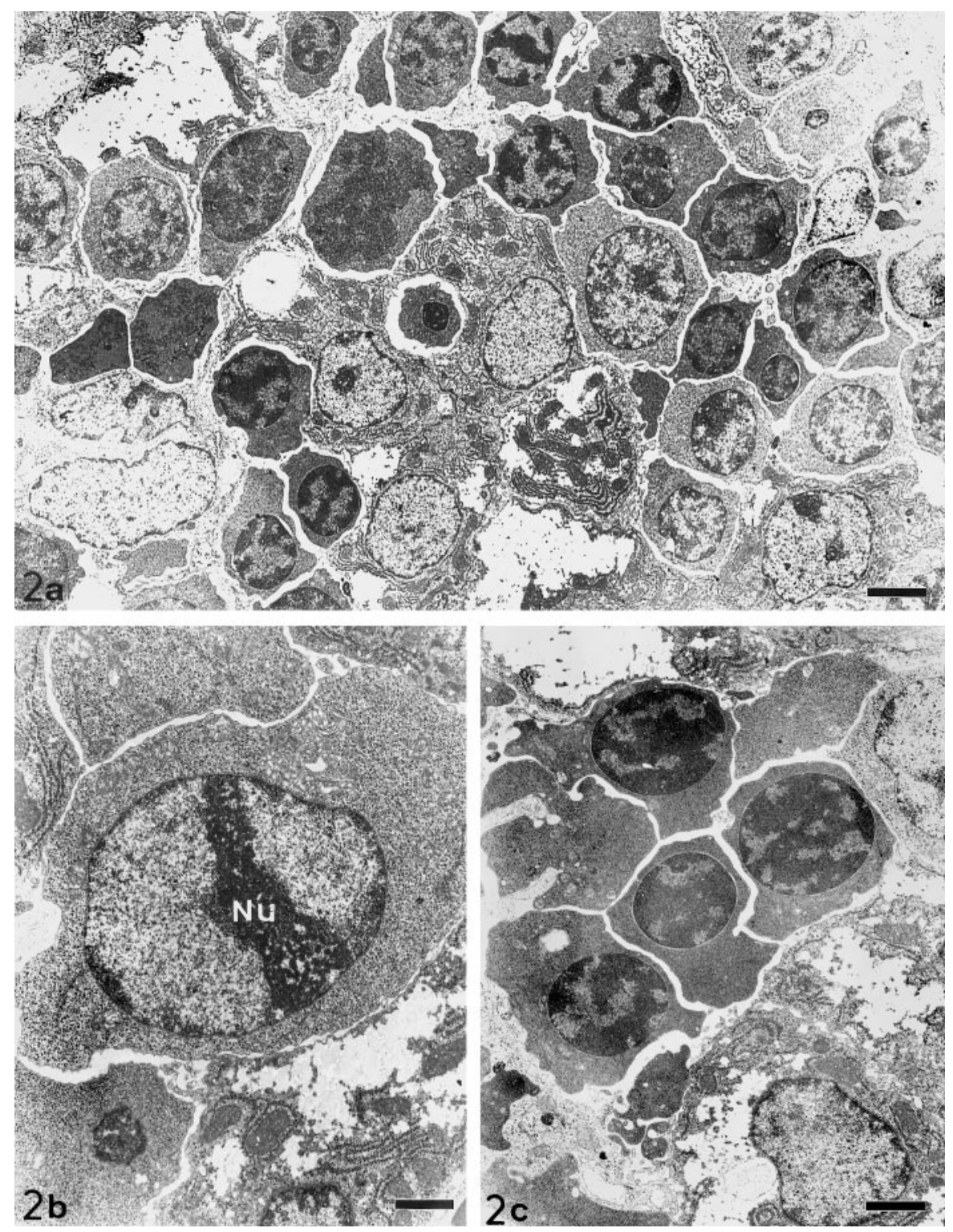

Fig. 2a. E-20 fetal liver from ADX group. Note the abundant hematopoietic cells and the hepatocytes with a few cytoplasmic organelles. Scale bar: $5 \mu \mathrm{m}$. Fig. $2 b$. E-20 ADX. Proerythroblast with a characteristic nucleolus $(\mathrm{Nu})$. Scale bar: $1.8 \mu \mathrm{m}$. Fig. 2 c. E-20 ADX. Clusters of polychromatophil erythrob lasts can be observed. Scale bar: $2.5 \mu \mathrm{m}$ 


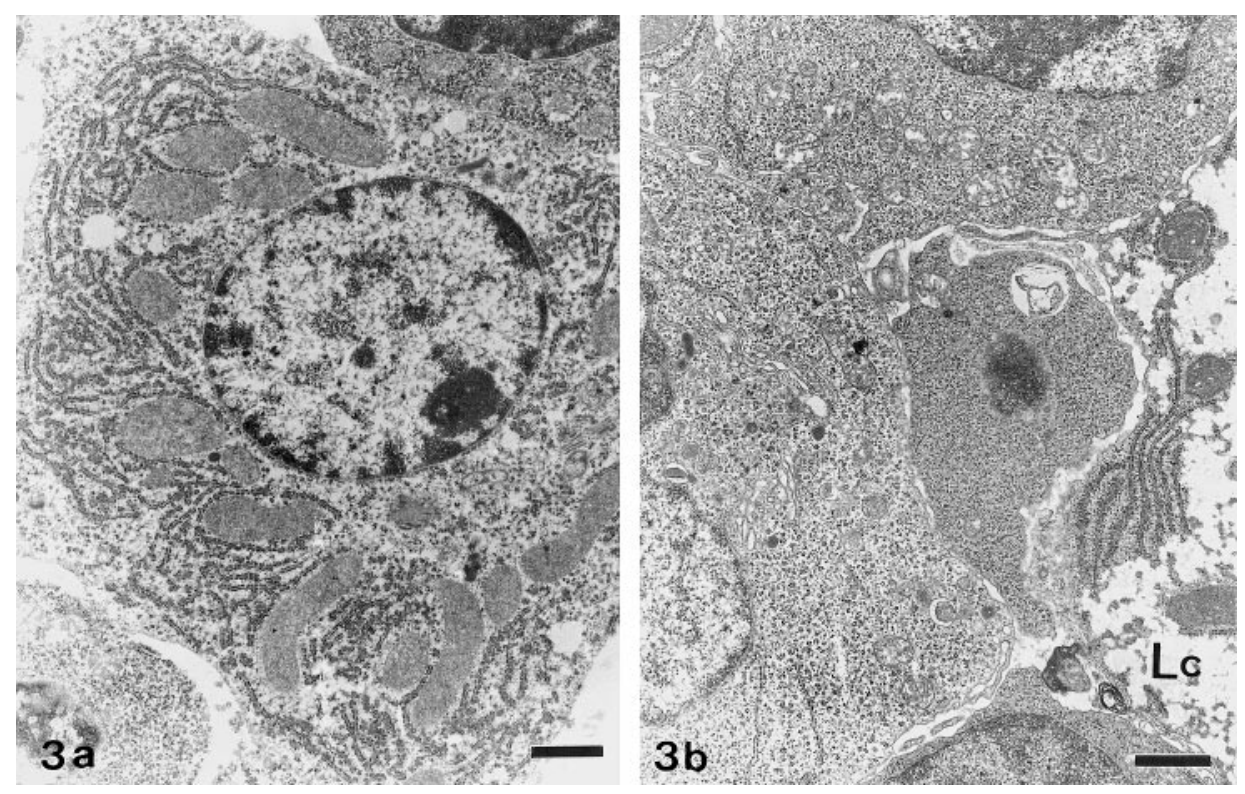

Fig. 3a. E-20 fetal liver from Control group. Detail of hepatocyte cell with abundant cytoplasmic organelles and scarce lipid amount. Scale bar: $1 \mu \mathrm{m}$. Fig. 3b. E-20 fetal liver from ADX group. We can see hepatocytes with numerous lipidic clusters (Lc) and a loss of cytoplasmic organelles. Scale bar: $1 \mu \mathrm{m}$

sessed relatively abundant rough endoplasmic reticulum, many mitochondria, and a few small lysosomal granules in their cytoplasm (Fig. 3a). The erythropoietic cells were round in shape, and their cytoplasm contained a sparse endoplasmic reticulum and a few mitochondria (Fig. 1a). After 20 days of gestation, the liver was composed of short cords of immature hepatocytes with cytoplasmic processes that surround the hematopoietic cells (Fig. 1b). All cellular strands of the erythropoietic cell line were observed. Basophilic erythroblasts had nuclei with no nucleoli, and little chromatinization (Fig. 1c). Nuclear heterochromatinization increased progressively in polychromatophils and normoblasts. Cells in their final stages of differentiation, such as granulocytes and metamyelocytic eosinophils with filober nuclei, and a heterogenous population of specific granules, and mature neutrophil granulocytes were observed (Figs 1d-1e).

\section{ADX groups}

The absence of maternal glucocorticoids during gestation induced important changes in both E17 and E20 hepatic parenchyma, consisting of an increase in the degree of tissue compression, a histological disorganization of the organ due to unclear definition of the hepatic cords and, finally, cellular lesions which mainly affect prehepatocyte cytoplasm causing a considerable loss of organelles (Figs 2a, 3b). No glyco- 


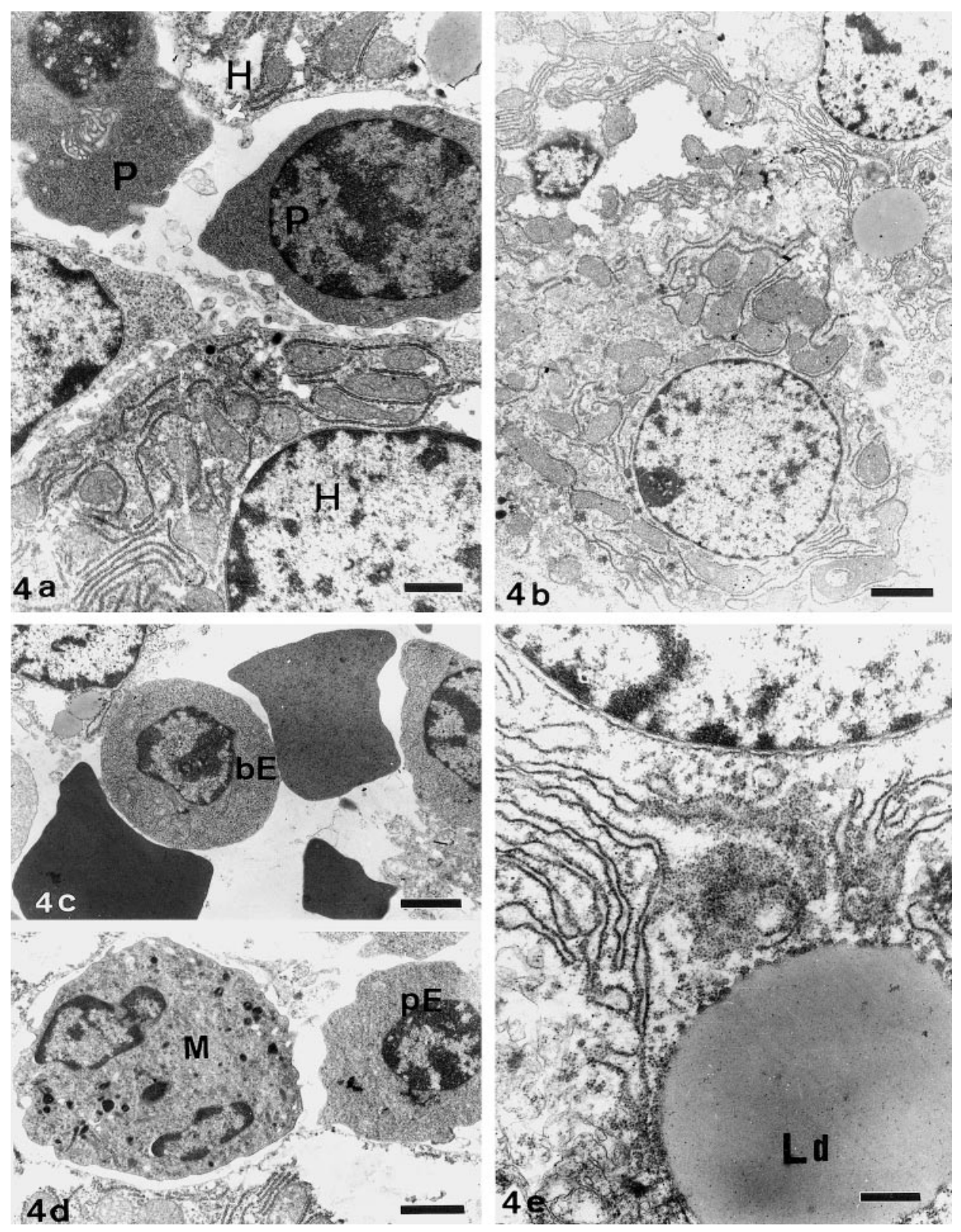

Fig. 4a. Electron micrograph of E-20 fetal liver from ADX+BET group. Between hepatocites $(\mathrm{H})$ we can see hematopoietic cells (P). Scale bar: $1.1 \mu \mathrm{m}$. Fig. 4b. E-20 ADX + BET. Hepatocytes contains numerous mitochondria, well-developed endoplasmic reticulum, and a few small lysosomes. Scale bar: $2.5 \mu \mathrm{m}$, Fig. 4c. E-20 ADX+BET. Basophilic erythrocytes (bE). Scale bar: $2.5 \mu \mathrm{m}$. Fig. 4d. E-20 ADX+BET. Metamielocyte $(\mathrm{M})$ and polychromatophilic erythroblasts $(\mathrm{pE})$ were observed. Scale bars: $1.8 \mu \mathrm{m}$. Fig. $4 e$. E-20 ADX+BET. Detail of hepatocite with abundant RER and a big Lipid droplet (Ld). Scale bar: $0.5 \mu \mathrm{m}$ 
tocyte cytoplasm causing a considerable loss of organelles (Figs 2a, 3b). No glycogen storage was observed in these experimental groups.

The hematopoietic component of fetal liver was more abundant in ADX than in the control group. The presence of proerythroblasts (Fig. 2b) and early promyelocytes, that do not appear in the 20 days old fetal liver under normal conditions, show that the ADX group displays an immaturate stage. Similarly, clusters, typical of organs with high erythropoietic activity, were also detected (Fig. 2c).

\section{$A D X+$ BET group}

The administration of dexamethasone on days 15, 16 and 17 of gestation to ADX females, produced a smaller degree of cellular lesions. Moreover, it induced rapid involution of the hematopoietic component that was still in an immature stage (Fig. 4a). The cytoplasm of the hepatocytes contained numerous mitochondria, welldeveloped rough endoplasmic reticulum, and a few small lysosomes (Fig. 4e). Bile canaliculi between the hepatocytes were well developed.

There was little hematopoietic activity and a clear immaturity shown by the presence of proerythroblasts, myelocytes, basophils and metamyelocyte neutrophils, and the absence of clusters (Figs 4c-4d).

\section{DISCUSSION}

In addition to the previously described effect of GCs in fetal liver maturation [6] and in the beginning of glycogen storage [13, 18, 31], our results report a further GC regulatory function in the liver prenatal stages. Endogenous corticoids cross the placental barrier [5,37]. The main sources of these hormones are the adrenal glands of both mother and fetuses, the latter beginning to secrete by embryonic days 17-18 [19, 25]. Thus, maternal adrenal glands are the main source of corticosterone during $80 \%$ of gestation but fetal adrenals can add corticosterone to the maternal compartment from day $17-18$ onwards [29].

The high number of fetal hepatic cell nuclei in the ADX group seems to indicate an increment in cell proliferation in fetal liver, on the contrary the lower protein content per nucleus suggests a delay in their maturation. Experiments performed in vitro and biochemical analysis support our observations in relation to the absence of maternal glucocorticoids during gestation that induces important changes in fetal hepatic parenchyma. Shiojiri and Mizuno [33] described that glucocorticoids are necessary for the differentiation of both immature and mature hepatocytes as well as biliary duct epithelial cells. Moreover, glucocorticoids contribute to the start of hepatic expression of specific adult liver genes [16]. The GCs also play a role in activating the genes involved in the onset of glycogen storage from day 18 of gestation, such as those encoding for fructose-1,6-biphosphate and glycogen synthetase [8]. In accordance with this, we found that, in the absence of maternal glucocorticoids, the fetal liver lacked glycogen reserves. The difference in the ADX and ADX + BET mothers 
is their different glucocorticoid levels on days 15 to 17 of gestation. The involution of hematopoiesis achieved in a few days confirms that the maternal glucocorticoids are responsible for cessation of fetal hepatic hematopoietic activity. This involution occurs in spite of the fact that the hematopoietic cells are at a relatively immature stage of development, suggesting that the presence of maternal glucocorticoids from the beginning of hematopoiesis is necessary for correct maturation of the hematopoietic cells.

After betamethasone injection in the ADX+BET group on days 15, 16 and 17 of gestation the normal fetal body weight was recovered, pointing to glucocorticoids as the cause of lower body fetal weight in ADX. It is therefore reasonable to assume that an absence of maternal glucocorticoids would damage fetal liver because of reducing glycogen storage. This is supported by the decreased liver weight we recorded under these circumstances.

It is well known that glucocorticoids inhibit erythropoietic synthesis in fetal hepatocytes in culture [24] and that the onset of fetal glucocorticoid production coincides with the onset of involution of fetal hematopoietic activity [28]. However, in the absence of maternal glucocorticoids there was no involution of hepatic hematopoiesis in spite of a hypertrophy of the fetal adrenal glands after maternal adrenalectomy $[10,23]$. These results could indicate that maternal and not fetal glucocorticoids are responsible for the cessation of hematopoietic activity.

Fetal hepatocyte lesions in the ADX group resulting from the lack of maternal glucocorticoids in the first 16 days of life do not reverse, although from this time fetal adrenal activity begins and the glucocorticoid supply becomes normal. All these results indicate the importance of maternal glucocorticoids from the beginning of gestation. Our study also shows that, in addition to their role in fetal hepatocyte differentiation and maturation, glucocorticoids may be also necessary for the maintenance of the structural integrity of the fetal liver throughout gestation.

\section{ACKNOWLEDGEMENTS}

This research was supported by a grant (218/94-5677) from Complutense University, Madrid, Spain. We are greateful to Agustín Fernandez from the Electron Microscopy Center, for technical assistance.

\section{REFERENCES}

1. Arahuetes, R. M., Carretero, V., Diebold, Y., Rúa, C. (1991) Effects of maternal bilateral adrenalectomy and betamethasone administration on fetal rat encephalic development. Biol. Neonate. 59, 303-313.

2. Ballard, P. L. (1979) Glucocorticoid and differentiation. In: Baxter, J. D., Rousseau, G. G. (eds) Glucocorticoid and differentiation. Springer Verlag, Berlin.

3. Benedetti, C. D., Pacheco, L. F., Anzola, G., Stopani, A. O. M. (1988) Hypophysectomy and adrenalectomy decrease $\mathrm{Ca}^{2+}$-induced swelling of rat liver mitochondria. Biochem. Intr. 17, 111-119.

4. Carretero, V., Arahuetes, R. M., Rúa, C. (1989) Influence of glucocorticoids in fetal encephalic development. J. Endocrinol. Invest. 12, 74. 
5. Chatelain, A., Dupouy, J. P., Allaume, P. (1980) Fetal-maternal adrenocorticotropin and corticosterone relationships in the rat: effects of maternal adrenalectomy. Endocrinology 106, 1297-1303.

6. Chou, J. Y. (1988) Regulators of fetal liver differentiation in vitro. Arch. Biochem. Biophys. 263, 378-386.

7. Cohen, A. (1973) Plasma corticosterone concentration in the fetal rat. Horm. Metab. Res. 5, 66.

8. Devi, B. G., Habeebullah, C. M., Gupta, P. D. (1992) Glycogen metabolism during human liver development. Biochem. Int. 28, 229-235.

9. Dupouy, M. J. P., Coffigny, H., Magre, S. (1970) Maternal and fetal corticosterone levels during late pregnancy in rats. J. Endocrinol. 65, 347-352.

10. Eguchi, Y. (1969) Physiology and pathology of adaptation mechanisms. New York, Pergamon Press.

11. Enesco, M., Leblond, C. P. (1962) Increase in cell number as a factor in the growth of the organs of the young male rat. J. Embriol. Exptl. Morphol. 10, 530-562.

12. Folch, J., Lees, M., Sloche-stanley, G. H. (1957) A simple method for the isolation and purification of fetal lipids from animal tissues. J. Biol. Chem. 226, 497-509.

13. Fulchignoni-lataud, M. C., Roux, J. M. (1979) The relationship of cell division to differentiation of the glycogen storage function in primary cultures of foetal rat hepatocytes. Biol. Cell 35, 39-44.

14. Hager, L. J., Mcknight, G. S., Palmiter, R. D. (1980) Glucocorticoid induction of egg-white mRNAs in chick oviduct. J. Biol. Chem. 225, 7796.

15. Higgins, S. T., Rousseau, G. G., Baxter, J. D., Tomkins, G. M. (1973) Early events in glucocorticoid action. J. Biol. Chem. 248, 5866-5872.

16. Hoopner, W., Sussmuth, W., O’Brien, C., Seitz, H. J. (1986) Cooperative effect of thyroid and glucocorticoid hormones on the induction of hepatic phosphoenolpiruvate carboxykinase in vivo and in cultured hepatocytes. Eur. J. Biochem. 159, 399-405.

17. Hynes, R. C. Jr., Murad, F. (1980) Adrenocorticotropic hormone; adrenocortical steroids and their synthetic analogs; inhibitors of adrenals and their synthetic analogs;inhibitors of adrenocortical steroid biosynthesis. In: Gilman, A. G., Goodman, A., Gilman A. (eds) Pharmacological basis of therapeutics. MacMillan, New York.

18. Jost, A. (1962) Hormonal factors controlling the storage of glycogen in the fetal liver. In: Cori, F., Foglia, A., Leloir, A., Ochoa, D. (eds) Perspectives in biology. Elsevier, Amsterdam.

19. Jost, A., Picon, L. (1970) Hormonal control of fetal development and metabolism. Adv. Metab. Dis. $184,123$.

20. Leret, M. L., Gonzalez, M. I., Arahuetes, R. M. (1993) Effect of maternal adrenal deprivation on the content of catecholamines in fetal brain. Life Sci. 52, 1609-1615.

21. Li, X., Song, L., Kolasa, K., Jope, P. S. (1992) Adrenalectomy potentiates immediate early gene expression in rat brain. J. Neurochem. 58, 2330-2333.

22. Lowry, O. H., Rosebrough, N. J., Farr, A. L., Randal, R. J. (1951) Protein measurement with the Folin phenol reagent. J. Biol. Chem. 193, 265-267.

23. Machín, C., Madrid, R., Rúa, C., Arahuetes, R. M. (1992) Influencia del estado adrenal materno sobre la glándula adrenal fetal. In: Alemany, A. (ed.) Historia Natural'91, Mallorca-Spain.

24. Mayeux, P., Billat, C., Felix, J. M., Jacquot, R. (1986) Mode of action of erythropoietin and glucocorticoids on the hepatic erythroid precursor cells: role of prostaglandins. Cell Differ. 18, 17-26.

25. Milkovic, S. K., Milkovic, L. K., Paunovic, J. (1973) The initiation of fetal adrenocorticotrophic activity in the rat. Endocrinology 92, 380.

26. Mcewen, B. S., Davis, P. J., Parsons, B., Pfaff, D. W. (1979) The brain as a target for steroid hormone action. Ann. Rev. Neurosci. 2, 65-112.

27. Muratmatsu, M., Tanaka, M., Fujita, A., Otomo, S., Aihara, H. (1984) Heterogeneity of binding sites for glucocorticoid and the glucocorticoid-receptor complex in rat livers. Japan J. Pharmacol 36, 87-95.

28. Nagel, J. (1968) Le tissue hematopoietique dans le foie foetal de rat au fin de gestation, I. Evolution normale au cours du dernier quart de la gestation. Arch. Anat. Micros. 57, 1-97.

29. Petropoulos, F. A., Lau, C. (1973) Foetoplacental contribution to the maternal corticosteroid pool in Long-Evans rats. J. Endocrinol 59, 83-184. 
30. Rúa, C., Trejo, J. L., Machín, C., Arahuetes, R. M. (1995) Effects of maternal adrenalectomy and glucocorticoid administration on the development of rat hippocampus. J. Brain. Res. 36, 473-484.

31. Sadava, D., Fryckman, P., Harris, E., Majereus, D., Mustard, J., Bernard, B. (1992) Development of enzymes of glycolysis and gluconeogenesis in human fetal liver. Biol. Neonate 62, 89-95.

32. Schneider, W. C. (1957) In: Colowick, H., Kaplan, E. (eds) Methods in enzymology. New York.

33. Shiojiri, N., Mizuno, T. (1993) Differentiation of functional hepatocytes and biliary epithelial cells from immature hepatocytes of the fetal mouse in vitro. Anat. Embryol. 187, 221-229.

34. Trejo, J. L., Machín, C., Arahuetes, R. M., Rúa, C. (1995) Influence of the maternal adrenalectomy and glucocorticoid administration on the development of rat cerebral cortex. Anat. Embryol. 192, 89-99.

35. Trejo, J. L., Rúa, C., Cuchillo, I., Machín, C. (1998) Calbindin-D28k- and astroglial proteininmunoreactivities, and ultrastructural differentiation in the prenatal rat cerebral cortex and hippocampus are affected by maternal adrenalectomy. Devel. Bain Research 108, 161-177.

36. Van Dijk, J. P., Challis, J. R. G. (1989) Control and ontogeny of hypothalamic-pituitary-adrenal function in the fetal rat. J. Dev. Physiol. 12, 1-9.

37. Zarrow, M. X., Philpott, J. E., Denenberg, V. H. (1970) Corticosterone passes from mother to young through placenta. Nature 226, 1058-1059. 